\title{
Injection of Acanthaster planci with thiosulfate-citrate-bile-sucrose agar (TCBS). II. Histopathological changes
}

\author{
J. A. Rivera-Posada ${ }^{1, *}$, M. Pratchett ${ }^{1}$, L. Owens ${ }^{2}$ \\ ${ }^{1}$ ARC Centre of Excellence for Coral Reef Studies, James Cook University, Townsville, Queensland 4812, Australia \\ ${ }^{2}$ School of Veterinary and Biomedical Sciences, James Cook University, Townsville, Queensland 4812, Australia
}

\begin{abstract}
We assessed histological changes in the tissues of the crown-of-thorns starfish Acanthaster planci (COTS) after injection of thiosulfate-citrate-bile-sucrose agar (TCBS) which was used as a disease inducer (potential outbreak control method), by conventional and scanning electron microscopy. Digestive glands were processed and stained with hematoxylin and eosin to describe the histological architecture of the intestinal epithelium. Subsequently comparison of healthy versus infected tissues and Gram stains were carried out to confirm bacterial occurrence on infected tissues, characterize the structural changes induced by bacterial communities in COTS tissues, and to determine if the histopathological changes of intestinal tissues were consistent with vibrio infection. TCBS injections induced marked epithelial desquamation, hypertrophy and hypersecretion of glandular cells, epithelial cell destruction, pyknosis, reduction of thickness and disorganization of connective tissue and associated nerve plexus, presence of bacterial colonies, irregular eosinophilic foci in glandular cells, brush border disruption, atrophy and detachment of intestinal microvilli and cell debris in the lumen. All these changes were attributed to a fulminating systemic dysbiosis and were consistent with vibrio infections.
\end{abstract}

KEY WORDS: Vibrio $\cdot$ Crown-of-thorns $\cdot$ Microbe-host tissue interactions $\cdot$ Pyloric caeca

\section{INTRODUCTION}

The ecological impact of the corallivorous crown-ofthorns (COTS) starfish Acanthaster planci is enormous. Outbreaks of $A$. planci are the principal cause of long-term coral loss at many locations in the Pacific, including Palau, Guam and Fiji (Bruno \& Selig 2007, Pratchett 2010). COTS represent the most significant biological disturbance to tropical coral reefs (Birkeland \& Lucas 1990), resulting in extensive (up to $90 \%$ ) mortality among reef-building and habitat-forming corals (Pratchett 2005, Pratchett et al. 2009). Attempts to control the outbreaks, either by collection of adult individuals followed by burial ashore, injections of starfish with toxic chemicals or underwater fences are expensive, time consuming and only feasible for small areas. Current control methods are ineffective in either eradicating the coral-feeding starfish or preventing further coral mortality.

Thiosulfate-citrate-bile-sucrose agar (TCBS) is a selective media culture that allows selective growth of vibrios while inhibiting Gram-positive organisms and suppressing coliforms. Rivera-Posada et al. (2011a, this issue) explored an alternative control method for injecting TCBS into COTS in order to induce a fatal disease that is transmitted to healthy in-contact COTS under favourable conditions. They hypothesize that inhibition of competitive bacteria and increases in vibrio cell densities $\left(10^{5}\right.$ to $10^{7}$ colony forming units [cfu] $\mathrm{ml}^{-1}$ ) induced by TCBS 
activate the quorum sensing (QS) mechanism of vibrios, turning on virulence factors and subsequently inducing rapid onset of symptoms followed by death. Moreover, molecular analysis with 16S rRNA, topA and $m r e B$ of bacterial assemblages recovered from infected tissues of COTS identified several vibrios of the Harveyi and Splendidus clades that have been frequently described as etiological agents of echinoderm diseases (Rivera-Posada et al. 2011a,b).

The pathogen-host epithelium interactions can be broadly categorized as (1) alterations in the structure and function of the tight junction barrier (erosion, ulceration, apoptosis etc); (2) induction of fluid and electrolyte secretion; and (3) activation of inflammatory cascades (Bock et al. 2001, Sicherer et al. 2001, Berkes et al. 2003). For instance, some pathogens use tight junction proteins as receptors for their attachment and subsequent internalization, and others destroy the junctions providing an entrance to the underlying tissues (Guttman \& Finlay 2009).

Vibrios as pathogenic agents disrupt the hydroelectric transport of ions, in particular $\mathrm{Na}, \mathrm{K}, \mathrm{Cl}$ and $\mathrm{HCO}_{3}$, inducing tissue structural changes and severe damage through different mechanisms (Berkes et al. 2003, Thompson et al. 2006, Khemiss et al. 2009). For example, Vibrio cholerae alters tight junction permeability through the use of a surface protein called the zonula occludens toxin, which is excreted upon contact with intestinal epithelial cells (Fasano et al. 1995, Uzzau et al. 1999). V. parahaemolyticus has a thermostable direct hemolysin toxin that induces intestinal fluid secretion of chloride, cytotoxicity, and a dose-dependent increase in intracellular calcium (Raimondi et al. 2000, Berkes et al. 2003).

Vibrio harveyi, which is one of the COTS pathogens previously reported by Rivera-Posada et al. $(2011 a, b)$, possesses several key virulence factors including the ability to attach and form biofilms, quorum sensing, and secretion of various extracellular products (ECPs) such as proteases, phospholipases, hemolysins, cytotoxins and ADP-ribosylating toxins that are mediated by specific bacteriophages. Proteases and hemolysins are considered to play a major role in host tissue liquefaction (Deane \& Woo 2005). These bacterial enzymes affect the physical properties of tissue matrices and intercellular spaces, thereby promoting the spread of the pathogen. For example, neuraminidase produced by Vibrio cholerae degrades neuraminic acid, an intercellular cement of the epithelial cells of the intestinal mucosa (Todar 2011). All pathogenic Vibrio species encompass extracellular chitinases as a virulent factor and have been described as the primary etiological agents of numerous diseases of marine invertebrates (Baumann et al. 1980, Huq et al. 1983). The presence of chitinases aids the invasion of the pathogen through the chitinous cuticle of marine invertebrates as well as providing nutrients and amino acids through the enzymatic degradation of host tissues (Goday 1990, Thompson et al. 2006).

While there are several different contributing mechanisms by which the immune system fails allowing infection, the means by which these processes are carried out in echinoderms is intricate and scarcely understood. Knowledge in relation to the mechanisms involved in the induction of infectious diseases and the host tissue response in echinoderms is lacking.

The purpose of this study was to (1) describe the anatomy and histology of COTS digestive glands; (2) compare healthy versus infected tissues and characterize the histopathological structural changes induced by TCBS injections in COTS tissues contributing to a better understanding of the pathogen-host interactions and physiological tissue responses involved in the induction of diseases in echinoderms; and (3) determine if the histopathological changes of intestinal tissues were consistent with vibrio infection. This is a segment of on-going work to evaluate whether TCBS injection could be a new tool for management of COTS outbreaks.

\section{MATERIALS AND METHODS}

\section{COTS collection}

Samples consisted of 16 digestive glands dissected from individual, adult sick COTS which were previously injected with TCBS to induce disease $(\mathrm{n}=12)$, and healthy $(\mathrm{n}=4)$ COTS collected at Lizard Island $\left(14^{\circ} 40^{\prime} \mathrm{S}, 145^{\circ} 27^{\prime} \mathrm{E}\right)$ located in the far northern section of the Great Barrier Reef (Rivera-Posada et al. 2011a).

\section{Histology}

Four normal digestive glands were aseptically dissected after arrival at Lizard Island Research Station (LIRS) laboratory and immediately fixed in $10 \%$ formalin (10 parts of formalin to 1 part of tissue) (Bancroft \& Stevens 1996). Twelve digestive glands of infected COTS previously injected with TCBS (Rivera-Posada et al. 2011a) were collected before death for better isolation of pathogens and to avoid 
the strong enzymatic activity in intestinal tissues after death that results in swelling of the villus, epithelial denudation and autolysis (McInnes 2005). Processing of COTS pyloric caeca for hematoxylin and eosin (H\&E) and Gram stains (GS) was performed as described in Bancroft \& Stevens (1996). All tissues were sectioned at $5 \mu \mathrm{m}$. Histological changes were evaluated in terms of the appearance of microvilli, cell debris, pyknosis, enterocyte detachment, bacteria-like particles, glandular cell hyperrophy and epithelial integrity (appearance and detachment of layers).

\section{Scanning electron microscopy}

Twelve samples of infected tissues were collected for scanning electron microscopy (SEM) to confirm the presence of bacteria and to determine the tissue penetration of bacterial assemblages. All samples were fixed for $16 \mathrm{~h}$ in a $3 \%$ glutaraldehyde solution in $0.1 \mathrm{M}$ cacodylate buffer ( $\mathrm{pH}$ 7.8). Then, after dehydration in graded alcohol (50, 70, 90, and 100\%), samples were critical-point dried, mounted on aluminum stubs, sputter-coated with gold and examined under a JEOL JSM-5410LV scanning microscope.

\section{RESULTS}

\section{Macroscopic observations}

During the early stage of the disease, COTS displayed loss of body wall turgor, dropping of spines and production of mucus at the tip of the spines. As the disease progressed, blisters on the dorsal integument broke through the skin surface and resulted in large, open sores that exposed the internal organs (Rivera-Posada et al. 2011a). COTS tissues showed a progressive breakdown of muscle, disorganization of connective tissue, and degeneration and disruption of the epithelium. Muscle layers continued to fragment until there was little intact muscle remaining inserted on the collagenous connective tissues. Tissue colouration was occasionally darker in late stages of disease (Fig. 1).

\section{Histology and histopathological changes}

Microscopically, COTS digestive glands consist of layers of connective tissue (CT), muscle (ME), brush border (BB), glandular cells (GC) which are involved in the control of digestive metabolism, and a basiepithelial nerve plexus (NP) which form an extensive nervous layer adjacent to the tunica serosa (TS). The basi-epithelial plexus is an important part of the ectoneural nervous system division which provides functional connectivity between the viscera and other divisions of the nervous system. It is formed by abundant fibres associated with muscle layers (ME) and a few scattered neuronal cell bodies (NP) (Fig. 2). Histopathological changes of affected COTS tissues after TCBS injection are detailed in Figs. 3 \& 4. Histological appearance of affected tissues was mainly characterised by strong disorganization and destruction of connective tissue and muscle fibres, enterocyte detachment, marked epithelial desquamation, pyknosis, hypertrophic glandular cells, moderate presence of bacterial colonies and disorganized basiepithelial nerve plexus (Figs. $3 \& 4$ ).

\section{Scanning electron microscopy (SEM)}

The epithelial surface was colonised by microorganisms in zones where patches of degrading epidermis were mixed with degrading, exposed connective tissue (Fig. 5a,b). In the affected zone, collagen fibres were disorganized (Fig. 5c). Three bacterial morphotypes were observed in the areas affected: ovoid bacteria, rod-shaped bacteria and clusters of more than 10 cells. Bacteria clusters were never observed at the surface of the healthy integument nor on ossicles. Bacteria were much more numerous at the border of the affected zone. Smooth ovoid bacteria (Fig. 5b,c,e), were more abundant than rodshaped bacteria.

\section{DISCUSSION}

The histopathological changes reported in this study are similar to those described in numerous animals affected by vibrios. The most significant histological change found in this study was the destruction, disorganization and significant reduction in the amount of COTS connective tissues (Figs. $1 \& 4$ ). This finding was consistent with Owens et al. (1992), who described a widespread colonisation of connective tissue by Vibrio harveyi in experimentally infected Penaeus esculentus. Interestingly $V$. harveyi was reported by Sutton et al. (1988) as a potential COTS pathogen and is also one of the pathogenic vibrios previously isolated from COTS infected tissues (RiveraPosada et al. 2011b). V. harveyi ECPs are well known 


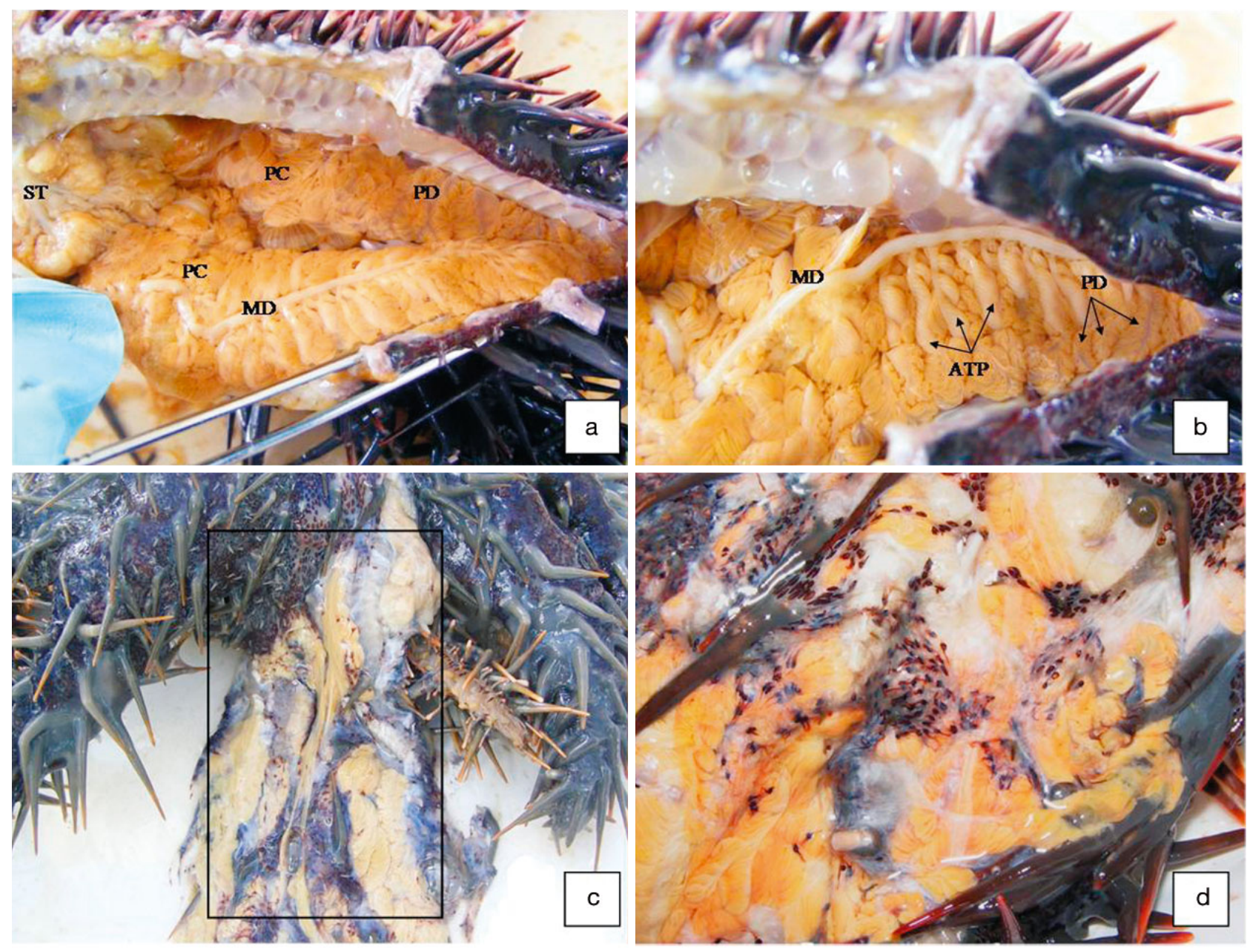

Fig. 1. Acanthaster planci. Macroscopic observations of crown-of-thorns starfish (COTS). (a,b) Normal appearance of A. planci digestive glands. (a) Paired pyloric caeca (PC) present in the coelomic cavity of each arm. Each pyloric caecum is connected to the dorsal part of the stomach (ST) and consists of a long median duct (MD) on which are numerous branched diverticula (PD). (b) Aboral view of COTS digestive glands; accessory Tiedemann's pouch (ATP), median duct of pyloric caeca (MD) and pyloric diverticulum (PD). (c,d) infected A. planci showing lysis of collagenous dermis and digestive glands with no observable pyloric caeca structure; (d) open lesions exposing internal organs, loss of epidermal tissue and marked lysis

for their capacity to induce lysis of connective tissue. For example, Zorrilla et al. (2003) evaluated the potential virulence role of $V$. harveyi and $V$. parahemolyticus extracellular products and reported that tissue lysis and ulcers were only seen on the surface of the fish after inoculation with ECPs from $V$. harveyi. Similarly, Zhang \& Austin (2000) demonstrated that the most pathogenic isolate of $V$. harveyi to salmonids produced ECPs with a maximum effect on fish tissues. This bacterium has also been reported as the etiological agent of body wall lesions in other echinoderms such as Tripneustes gratilla and Apostichopus japonicus (Ma et al. 2006, Becker et al. 2007).

The clinical signs of the disease induced by TCBS injections in COTS, such as necrotic skin, open sores, and loss of body turgor (Rivera-Posada et al. 2011a), have also been described in humans infected by vibrios as strong reactions in connective tissues characterized by necrosis and blisters (Chuang et al. 1992). Marked pyknosis was observed in all samples analyzed in the present study (2.5 over a scale of 0 to 3 ) (Fig. 3). Not surprisingly, V. harveyi ECPs induced degeneration of Penaeus monodon intestinal matrix cells, characterized by prominent pyknosis (Intaraprasong et al. 2009).

Moreover, our macroscopic and SEM analysis (Figs. 1 \& 5) displayed large amounts of disorganized and degraded collagen tissues and abundant miscellaneous bacteria. Becker et al. (2004) also used SEM analysis to describe skin ulceration disease in cultivated juveniles of Holothuria scabra (Holothuroidea, Echinodermata) and, similarly to our present study, 


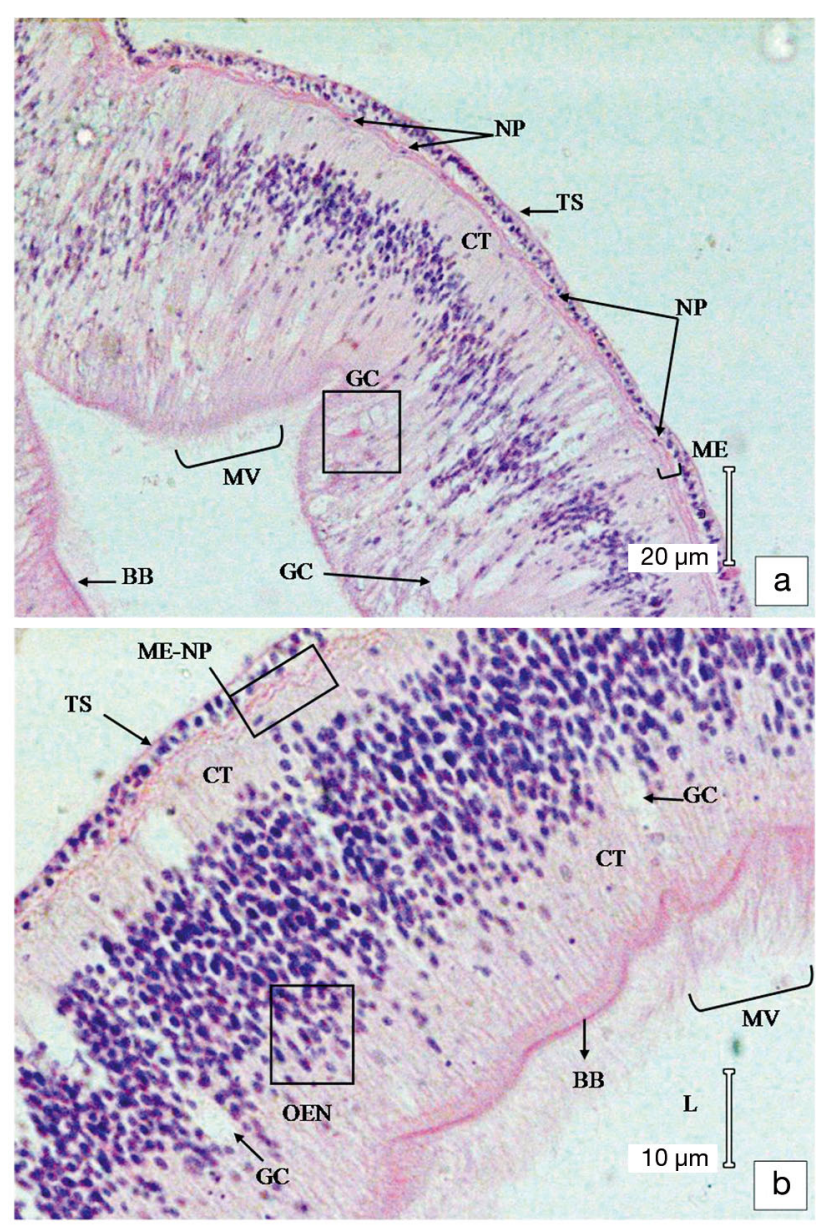

Fig. 2. Acanthaster planci. Histological appearance of normal digestive glands. Hematoxylin and eosin stain (H\&E). (a) 20×, (b) 40x magnification: A. planci intestinal wall from the lumen (L) to the periphery consists of a lamina of cylindrical simple-ciliated epithelia (MV) with ovoid-elongated nucleus (OEN) and thin brush border (BB), a moderate amount of glandular cells (GC) associated with a basi-epithelial nerve plexus (BNP), including, more externally, a layer of loose connective tissue (CT), a muscular epithelium (ME) associated with a nerve plexus (NP) and a tunica serosa (TS)

found zones where the epidermis was totally destroyed, highly degraded collagen fibers and ossicles were exposed to the external medium, and areas with bacterial assemblages of various morphotypes were present. These remarkable similarities between studies coupled with the identification of Vibrio sp., $V$. natriegens, $V$. harveyi and $V$. alginolyticus as etiological agents of skin ulceration disease in Holothuria scabra (Becker et al. 2004) and V. natriegens, $V$. harveyi, V. rotiferianus, $V$. owensii, and $V$. fortis in infected COTS tissues after injections with TCBS (Rivera-Posada et al. 2011a,b) clearly showed that members of the $V$. harveyi group are major etiological agents in the induction of diseases in echino-

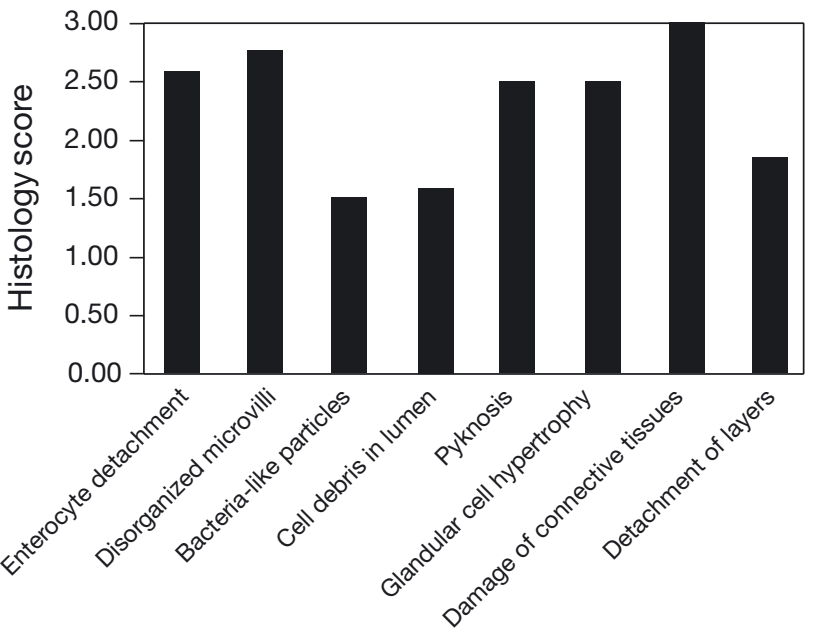

Fig. 3. Acanthaster planci. Morphological description of lesions in pyloric caeca after injection of thiosulfate-citratebile-sucrose agar (TCBS) media culture. Damage and tissue changes were assessed as follows: $0=$ not observed, $1=$ low frequency, 2 = moderate frequency, 3 = high frequency

derms. Furthermore, these findings confirmed that tissue structural changes in diseased echinoderms can be promoted by miscellaneous bacteria. Certainly, the marine environment is a rich source of opportunistic microorganisms that normally do not cause disease but become pathogenic when the immune system is impaired and unable to fight off infection.

COTS digestive glands showed areas of epithelial cell destruction, microvilli atrophy, enterocyte detachment, absence of muscular epithelium, reduction of thickness and disorganization of connective tissue and their associated nerve plexus, presence of bacterial colonies, cell debris in the lumen and marked epithelial desquamation (Figs. 4 \& 5) which is well known as an innate defense mechanism of the immune system that helps remove bacteria and other infectious agents that have adhered to the epithelial surfaces (Šturtinová et al. 1995). All these histological findings are also in agreement with other reports from marine invertebrates infected by vibrios. For example, histological evaluations of sea bream Sparus aurata intestines infected with Vibrio vulnificus described changes such as detachment of enterocytes, disorganized intestinal layers, inflammation, and alterations in the microvilli and brush border (Khemiss et al. 2009). V. harveyi caused a massive destruction of Penaeus monodon digestive system where epithelial cells and basement membrane were damaged, necrotic and completely disappeared in advanced stages of the disease. Bacterial clusters among cell debris in the lumen were also described (Soonthornchai et al. 2010). Furthermore, the hyper- 


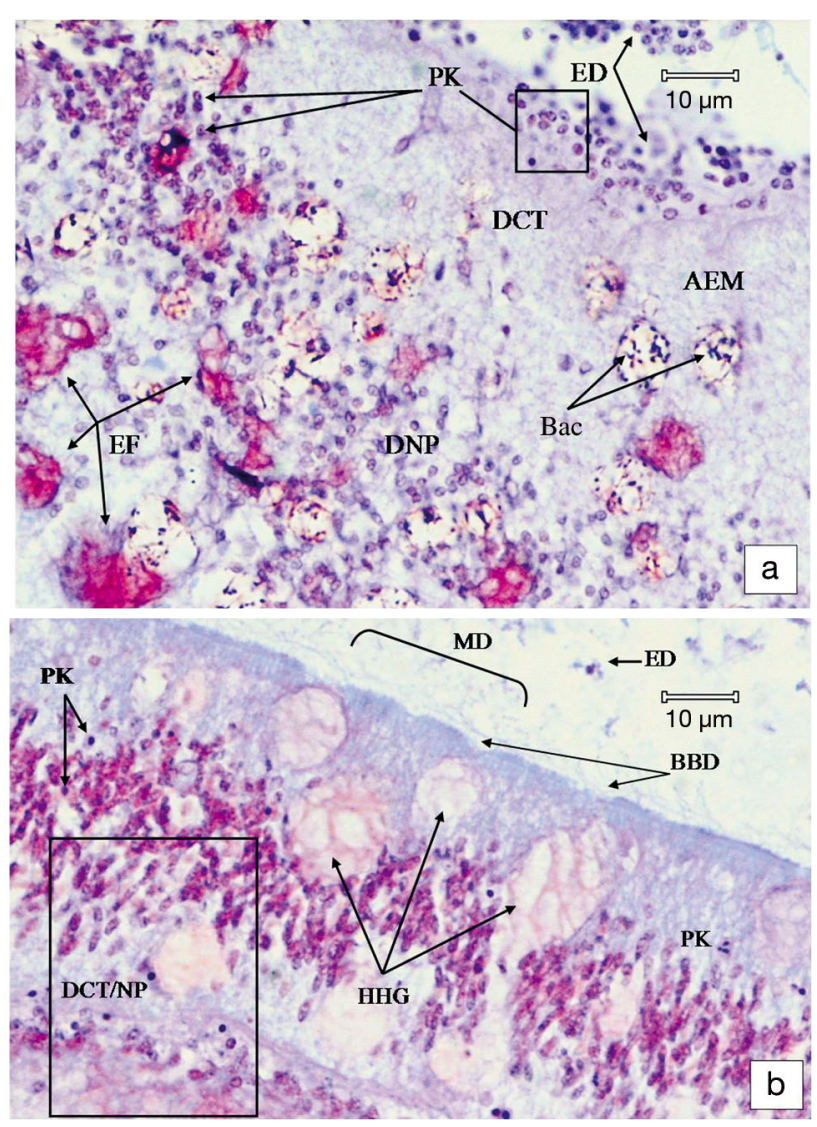

Fig. 4. Acanthaster planci. Histological appearance of affected tissues. (a) 40× magnification; irregular eosinophilic foci in glandular cells (EF), enterocyte detachment (ED), moderate presence of bacterial colonies (Bac), disorganization of basi-epithelial nerve plexus (DNP), pyknosis (PK), absence of epithelial muscle (AEM), reduction and disorganization of connective tissues (DCT). (b) 40× magnification; hypertrophic and hypersecreting glandular cells (HHG), marked epithelial desquamation (MD), brush border disruption (BBD), disorganized basi-epithelial nerve plexus (NP) and pyknosis (PK)

secreting intestinal glandular cells displayed in the present study (Fig. 4B) can be associated with the release of vibrio enterotoxins which are recognized for their capacity to induce intestinal fluid secretion, inflammation and severe tissue damage (Raimondi et al. 2000, Thompson et al. 2006).

There was good agreement between the histopathology findings, bacterial culture and identification (Rivera-Posada et al. 2011a,b, present study), suggesting that histopathological examination is a reliable tool that allowed identification of typical vibriosis lesions and could contribute to the differentiation from other causes. Varello et al. (2008) compared histologic techniques and bacteria cultures for the diagnosis of bovine tuberculosis reporting similar results.
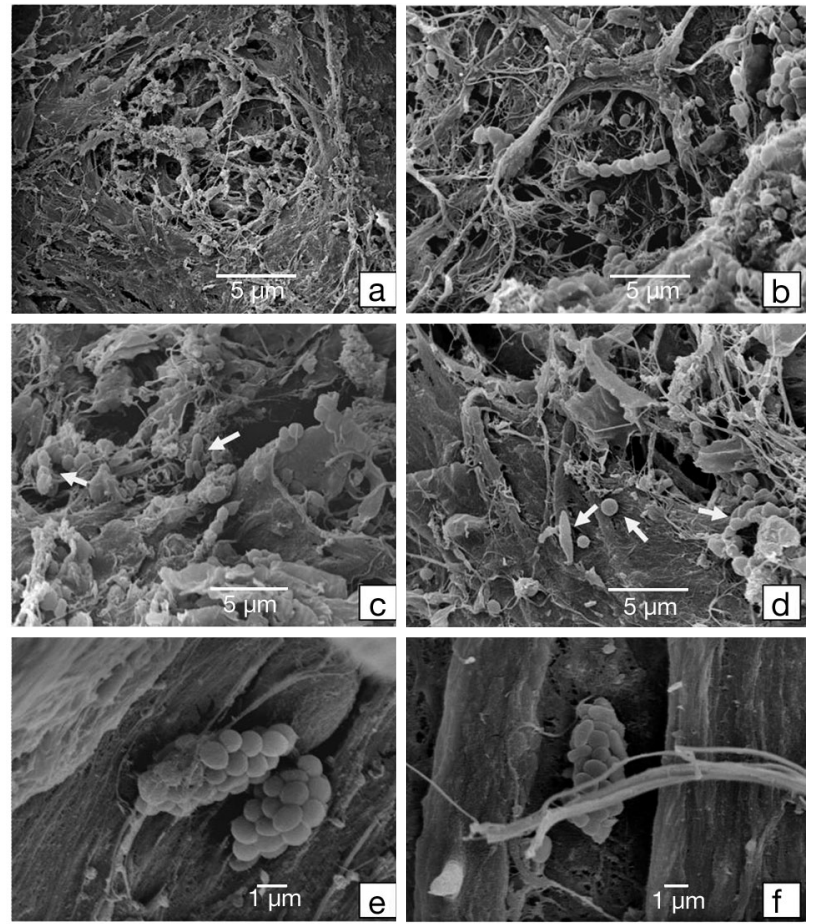

Fig. 5. Acanthaster planci. Scanning electron microscopy of tissues affected by bacterial assemblages. $(a, b)$ Disorganization of connective tissue, degeneration and disruption of epithelium and significant amounts of fibrin-like tissue over the samples. (b) Magnification of (a) Bacterial cluster inside the lesion suspended between degraded tissue. (c-f) Bacterial assemblages (arrows) of diverse morphology and size; smooth, ovoid, rod shaped and clusters

The present study showed that bacteria assemblages found on affected COTS tissues played an important role in the development of disease supporting the hypothesis of activation of quorum sensing mechanism proposed by Rivera-Posada et al. (2011a). However, being opportunistic species, vibrios can evolve and recombine when reaching high densities in animal guts or as part of aquatic biofilms, transferring or inducing expression of virulence genes in less or non-pathogenic populations (Thompson et al. 2004). Therefore, Vibrio quorum sensing studies are important to understand the pathways used to drive the presentation of the transmissible disease in COTS.

Knowledge of the signaling molecules involved in the QS process and their inter-relationship will allow a better understanding of the interaction between bacteria and host. It will also provide insight into the effects of transmissible disease on other marine animals that also have vibrios of the Harveyi and Splendidus clades as normal inhabitants. Disease dynamics and transmission experiments are warranted, 
especially in corals, carnivorous fishes, and benthic detritus feeders.

After several decades of research, current control methods are ineffective in either eradicating the coral-feeding starfish or preventing further coral mortality. The susceptibility of crown-of-thorns starfish Acanthaster planci to disease could provide an option for controlling population outbreaks. Injection of TCBS culture medium into A. planci induces a rapid fulminating disease that is transmitted to incontact COTS under favourable conditions (RiveraPosada et al. 2011a). Additionally there is no introduction of new pathogens into the environment and it is a rapid and simple procedure with immense economic advantages.

Acknowledgements. Funding for this project was provided by the ARC Centre of Excellence for Coral Reef Studies, Queensland, Australia.

\section{LITERATURE CITED}

Bancroft JD, Stevens A (1996) Theory and practice of histological techniques, 4th edn. Churchill Livingstone, New York, NY

Baumann P, Baumann L, Bang S, Woolkalis M (1980) Reevaluation of the taxonomy of Vibrio, Beneckea and Photobacterium: Abolition of the genus Beneckea. Curr Microbiol 4:127-132

Becker P, Gillan D, Lanterbecq D, Jangoux M, Rasolofonirin R, Rakotovao J, Eeckhaut I (2004) The skin ulceration disease in cultivated juveniles of Holothuria scabra (Holothuroidea, Echinodermata). Aquaculture 242:13-30

> Becker P, Gillan DC, Eeckhaut I (2007) Microbiological study of the body wall lesions of the echinoid Tripneustes gratilla. Dis Aquat Org 77:73-82

Berkes J, Viswanathan VK, Savkovic SD, Hecht G (2003) Intestinal epithelial responses to enteric ion transport, and inflammation pathogens: effects on the tight junction barrier. Gut 52:439-451

Birkeland C, Lucas J (1990) Acanthaster planci: major management problem of coral reefs. CRC press, Boca Raton, FL

> Bock SA, Muñoz-Furlong A, Sampson HA (2001) Fatalities due to anaphylactic reactions to foods. J Allergy Clin Immunol 107:191-193

> Bruno JF, Selig ER (2007) Regional decline of coral cover in the Indo-Pacific: timing, extent, and subregional comparisons. PLoS One 2:e711

Chuang YC, Yuan CY, Liu CY, Lan CK, Huang AH (1992) Vibrio vulnificus infection in Taiwan: report of 28 cases and review of clinical manifestations and treatment. Clin Infect Dis 15:271-276

$>$ Deane EE, Woo NYS (2005) Evidence for disruption of $\mathrm{Na}^{+}$$\mathrm{K}^{+}$-ATPase and hsp70 during vibriosis of sea bream, Sparus (=Rhabdosargus) sarba Forsskål. J Fish Dis 28: $239-251$

Fasano A, Fiorentini C, Donelli G, Uzzau S and others (1995) Zonula occludens toxin modulates tight junctions through protein kinase $\mathrm{C}$-dependent actin reorganization, in vitro. J Clin Invest 96:710-720
Goday G (1990) The ecology of chitin degradation. Adv Microb Ecol 11:387-430

Guttman JA, Finlay BB (2009) Tight junctions as targets of infectious agents. Biochim Biophys Acta 1788:832-841

> Huq A, Small EB, West PA, Huq MI, Rahman R, Colwell RR (1983) Ecological relationships between Vibrio cholerae and planktonic crustacean copepods. Appl Environ Microbiol 45:275-283

Intaraprasong A, Khemayan K, Pasharawipas T, Flegel TW (2009) Species-specific virulence of Vibrio harveyi for black tiger shrimp is associated with bacteriophagemediated hemocyte agglutination. Aquaculture 296: 185-192

Khemiss F, Ahmadi S, Massoudi R, Ghoul-Mazgar S, Safta S, Moshtaghie AA, Saidane D (2009) Effect of in vitro exposure to Vibrio vulnificus on hydroelectrolytic transport and structural changes of sea bream (Sparus aurata L.) intestine. Fish Physiol Biochem 35:541-549

Ma YX, Xu GR, Chang YQ, Zhang EP, Zhou W, Song LS (2006) Bacterial pathogens of skin ulceration disease in cultured sea cucumber Apostichopus japonicus (Selenka) juveniles. J Dalian Fish Univ 21:13-18 (in Chinese, with English abstract)

McInnes E (2005) Artifacts in histopathology. Comp Clin Pathol 13:100-108

Owens L, Muir P, Sutton D, Wingfields M (1992) The pathology of microbial disease in tropical Australian Crustacea. In: Shariff M, Subasinghe RP, Arthur JR (eds) Diseases in Asian aquaculture. Fish Health Section, Asian Fisheries Society, Manila, p 165-172

Pratchett MS (2005) Dynamics of an outbreak population of Acanthaster planci at Lizard Island, northern Great Barrier Reef (1995-1999). Coral Reefs 24:453-462

Pratchett MS (2010) Changes in coral assemblages during an outbreak of Acanthaster planci at Lizard Island, northern Great Barrier Reef (1995-1999). Coral Reefs 29: 717-725

> Pratchett MS, Schenk TJ, Baine M, Syms C, Baird AH (2009) Selective coral mortality associated with outbreaks of Acanthaster planci L. in Bootless Bay, Papua New Guinea. Mar Environ Res 67:230-236

Raimondi F, Kao J, Fiorentini C (2000) Enterotoxicity and cytotoxicity of Vibrio parahaemolyticus thermostable direct hemolysin in in vitro systems. Infect Immun 68: 3180-3185

> Rivera-Posada JA, Pratchett M, Cano-Gómez A, ArangoGómez JD, Owens L (2011a) Injection of Acanthaster planci with thiosulfate-citrate-bile-sucrose agar (TCBS). I. Disease induction. Dis Aquat Org 97:85-94

> Rivera-Posada JA, Pratchett M, Cano-Gomez A, ArangoGomez JD, Owens L (2011b) Refined identification of Vibrio bacterial flora from Acanthasther planci based on biochemical profiling and analysis of housekeeping genes. Dis Aquat Org 96:113-126

> Sicherer SH, Sampson HA, Bock SA, Muñoz-Furlong A (2001) Underrepresentation of the risk and incidence of anaphylaxis to foods. Arch Intern Med 161:2046-2047

Soonthornchai W, Rungrassamee W, Karoonuthaisiri N, Jarayabhand $\mathrm{P}$, Klinbunga S, Soderhall K, Jiravanichpaisal P (2010) Expression of immune-related genes in the digestive organ of shrimp, Penaeus monodon, after an oral infection by Vibrio harveyi. Dev Comp Immunol $34: 19-28$

Štvrtinová V, Jakubovský J, Hulín I (1995) Inflammation and fever. Pathophysiology: principles of disease. Slovak 
Academic Press, Bratislava. Available at http://staryweb. fmed.uniba.sk/patfyz/zapalweb/Inffever.html (Accessed: 15 December, 2010)

Sutton DC, Trott L, Reichelt JL, Lucas JS (1988) Assessment of bacterial pathogenesis in crown-of-thorns starfish, Acanthaster planci (L.). Proc 6th Int Coral Reef Symp, Townsville 2:171-176

Thompson FL, Iida T, Swings J (2004) Biodiversity of vibrios. Microbiol Mol Biol Rev 68:403-431

Thompson FL, Austin B, Swings J (2006) The biology of vibrios. ASM Press, Washington, DC

Todar K (2011) Todar's online textbook of bacteriology. Available at http://www.textbookofbacteriology.net/ (Accessed 19 February 2011)

Uzzau S, Cappuccinelli P, Fasano A (1999) Expression of

Editorial responsibility: David Bruno,

Aberdeen, UK
Vibrio cholerae zonula occludens toxin and analysis of its subcellular localization. Microb Pathog 27:377-385

Varello K, Pezzolato M, Mascarino D, Ingravalle F, Caramelli M, Bozzetta E (2008) Comparison of histologic techniques for the diagnosis of bovine tuberculosis in the framework of eradication programs. J Vet Diagn Invest 20:164-169

Zhang XH, Austin B (2000) Pathogenicity of Vibrio harveyi to salmonids. J Fish Dis 23:93-102

Zorrilla I, Arijo S, Chabrillon M, Diaz P, MartinezManzanares E, Balebona MC, Moriñigo MA (2003) Vibrio species isolated from diseased farmed sole, Solea senegalensis (Kaup), and evaluation of the potential virulence role of their extracellular products. J Fish Dis 26: 103-108

Submitted: March 1, 2011; Accepted: July 22, 2011

Proofs received from author(s): October 31, 2011 